\title{
Enhancing the Operational Effectiveness of Savings and Credit Cooperative Societies for Sustainable Growth
}

http://doi.org/10.21272/fmir.3(2).59-68.2019

\section{Kowo Solomon Akpoviroro}

Department of Business Administration, Kwara State University, Nigeria

\section{Sabitu Olalekan Owotutu}

Department of Business Administration, Ogun State Institute of Technology Igbesa, Nigeria

\author{
Adegbite Ganiu Adewale
}

Department of Marketing, Ogun State Institute of Technology Igbesa, Nigeria

\begin{abstract}
The problem of cooperative societies in developing countries has received the attention of many experts and researchers as well the government, this is because it constitutes a serious bottleneck to the economic development of the country as well the communities. For the purpose of this study, the survey method and expost facto method was employed. Relevant data was collected at the same instance; a cross-sectional design was adopted. The population was limited to all co-operators of the cooperative's societies in two (2) selected Paramilitary Organizations in Ogun state. The two cooperatives chosen are Nigeria Security and Civil Defence Corps (NSCDC) and the Nigeria Immigration Service (NIS). For this study the sample size was determined using Yarmane formula. The data was analyzed using manual and electronic based methods through the data preparation grid and statistical package for the social sciences, (SPSS). It also made use of statistical tools which included: analysis of variance (ANOVA), correlation efficient and regression analysis in testing the research hypotheses. Internal consistency was measured by Cronbach Alpha of 0.885 . The study found out that there is a significant relationship between loan repayment, savings plan and satisfaction of members of cooperative societies in Paramilitary in Ogun state and also there exist a significant relationship between modus operandi of cooperative societies and membership of Paramilitary in Ogun state. Thus, the study recommends that active collaboration of cooperative society with the Organized Private Sector, Bank of Industry as well as the Federal Ministry of Trade and Investment could go a long way in ensuring that the objectives of this Agency are realized for the benefit of the average Nigerian.
\end{abstract}

Keywords: Co-operatives, Modus of Operandi, Loan repayment, Savings Plan.

JEL Classification: G2, G21.

(C) The Authors, 2019. This article is published with open access at Sumy State University.

Cite as: Kowo, Ak.S., Owotutu, S. Ol., Adewale Ad. G. (2019). Enhancing the Operational Effectiveness of Savings and Credit Cooperative Societies for Sustainable Growth. Financial Markets, Institutions and Risks, 3(2), 59-68. http://doi.org/10.21272/fmir.3(2).59-68.2019.

\section{Introduction}

It is an established fact that today, in an era when many people feel powerless to change their lives, cooperatives represent a strong, vibrant, and viable economic alternative (Aresvik, 2008). Cooperatives are formed to meet peoples' mutual needs (Anderson, 1993). They are based on the powerful idea that together; a group of people can achieve goals that none of them could achieve alone. For over 160 years now, cooperatives have been an effective way for people to exert control over their economic livelihoods (Micheal, 2009; Olumidu, 2009; Asaolu, 2004 \& Harmer, 2001). As government around the world cut services and withdraw from regulating markets, cooperatives are being considered useful mechanisms to manage risk for members in Agricultural or other sectors. Cooperatives help salary/wage earners to save for the future through a soft-felt monthly contribution that is deducted from source, own what might be difficult for individuals to own by their efforts, strengthen the communities in which they operate through job provision and payment of local taxes (Akinwunmi, 2006). Incidentally, cooperative despite its old age is not very popular in Nigeria. Only recently worker cooperatives started gaining ground among working class citizens, most of who find it 
Financial Markets, Institutions and Risks, Volume 3, Issue 2, 2019

ISSN (online) - 2521-1242 ISSN (print) - 2521-1250

difficult to save part of their salaries/wages for the rainy day. Cooperatives are much needed in a country where majority of the citizens are workers, civil /Public servants. It has been observed that little attention has been given to this aspect of cooperative unlike agricultural cooperative. Over the times, there have been a lot of attentions on agricultural produce with little or no emphasis on Public/civil servants. There is need to study how these workers engage in cooperatives, the module operandi and how they satisfy members. According to Gounans (2003), Consumers purchase decision and behaviour as well as his consumption patterns are constrained and directed by multiplicity factors, some of which are outside his control. Some of the factors shape his needs and habits, some others determine his purchasing power. The life of any business depends on its ability to make surplus and plough it back into the business, this also applies to cooperative. For this reasons, level of patronage becomes a very important aspect of their existence (Fornell, 1992). This study will also examine level of patronage in order to evaluate patronage and how it affects the life of cooperative through the interest rate. There are different types of cooperative societies, and they cut across different sectors, some includes Producer's cooperative societies, consumer's cooperative societies, marketing cooperative societies, credit cooperative societies, farming cooperative societies, housing cooperative societies, insurance cooperative societies and transport cooperative societies.

\section{Statement of research problems}

Satisfied customers are perceived as indispensible means of creating sustainable advantage in competitive environments (Patterson, Johnson and Spreng, 1997). Anderson \& Sullivan (1993) stated the following: "investing in customer's satisfaction is like taking out the insurance policy. If some hardship temporarily befalls the firm, the customers will be more likely to remain loyal". This study intends to find out the extent to which savings plan and loan repayment affects the satisfaction of members. Members derive a lot of benefits by joining a cooperative society which urges them to patronize the cooperative store. Some of the benefits according to Igwe (2006) are that the membership affords one the opportunity of buying goods at a very cheaper price. The cheapness of the goods helps the members to save money thereby contributing to improvement of the socio-economic status of members. The modus of operandi of cooperatives is important to membership of cooperatives, so this study intends to determine how modes of operation adopted by cooperatives improve or affects the membership of cooperatives. This research seeks to answer the following questions. (i) Does loan repayment affect the satisfaction of members of cooperative societies in Paramilitary in Ogun state? (ii)To what extent does modus of operandi of cooperative societies affects the membership of such cooperative societies in Paramilitary in Ogun state?

\section{Objective of the study}

i. To determine the level to which loan repayment and savings plan of cooperative societies will affect satisfaction of its members

ii. To highlight the extent to which modus of operandi will affect the membership of the cooperative's societies.

\section{Research Hypothesis}

H0i: Loan repayment and savings plan does not significantly affect the satisfaction of members of cooperative societies in in Paramilitary in Ogun state

H0ii: Modus operandi of cooperative societies in Paramilitary in Ogun state does not affects membership of the cooperative's societies.

\section{Literature Review}

The Concept of cooperative societies. Alaba et al, (2007) defines a cooperative as "an autonomous association of persons united voluntarily to meet their common economic, social, and cultural needs and aspirations through a jointly-owned and democratically-controlled enterprise." It is a business voluntarily owned and controlled by its member patrons and operated for them and by them on a nonprofit or cost basis (Adekunle \& Henson, 2007). Aryeetey (1997) postulate that co-operative society is a voluntary association of individuals having common needs, who join hands for the achievement of common economic interest. Its aim is to serve the interest of the poorer sections of society through the principle of self-help and mutual help. The main objective is to provide support to the members. Nobody joins a cooperative society to earn profit. People come forward as a group, pool their individual resources, utilise them in the best possible manner, and 
Financial Markets, Institutions and Risks, Volume 3, Issue 2, 2019

ISSN (online) - 2521-1242 ISSN (print) - 2521-1250

derive some common benefit out of it (Garnett, 2012). A Co-operative Society can be formed as per the provisions of the Co-operative Societies Act, 1912. At least ten persons above of 18 years, having the capacity to enter into a contract with common economic objectives, like farming, weaving, consuming, etc. can form a Co-operative Society. Cooperative Societies Act is a Central Act. However, 'Cooperative Societies' is a State Subject (Entry 32 of List II of Seventh Schedule to Constitution, i.e. State List). Though the Act is still in force, it has been specifically repealed in almost all the States and those States have their own Cooperative Societies Act. Thus, practically, the Central Act is mainly of academic interest and as per preamble to the Act, the Act is to facilitate formation of cooperative societies for the promotion of thrift and self-help among agriculturists, artisans and persons of limited means.

The concept of credit. Credit as the name implies entails empowerment through the availability of fund to low income earners in a non-formal setting, which is characterized as traditional financial institutions (TFI) (Gounans, 2007). The importance of credit to staffs cannot be overemphasized because credit enables business owners to advantageously use inputs and factors of production by granting them more access to resources through removal of financial constraints. The traditional argument for the provision of credit is that additional capital can be temporarily used to enhance the level of household productive and physical capital (Harmer, 2001). Asaolu (2004) regarded credit has soft loans usually given to craftsmen, farmers, small and medium scale entrepreneurs and staffs as well as to increase their general welfare. Micheal (2009) observed that an increase in credit and loans to staffs will enhance improvement of employee's wellbeing.

\section{Significance of Cooperative Societies}

Cooperative societies are formed based on certain principles which distinguished them from other business organizations. Sharma \& Patterson (2000) asserts that such principles may be based upon the new models of scientific management of businesses and applied economics. Similarly, Hammer (2001) and Alaba et al, (2007) posit that there is a great distinction between cooperative societies and non-cooperative businesses. The introduction of cooperative societies is to remove the evil effects of the capitalist system of production which did not go down well with the common man's aspiration. Cooperative societies are known to bring about low prices of goods. Goods are bought directly from manufacturers at factory prices and sold to members at controlled prices thereby making their selling prices to be lower than the operating prices in the open market (Aresrik, 2008). Cooperatives are managed along democratic lines. Members, for instance, have equal voting rights, equal opportunity to participate in the management and control of the societies and make inputs to policies (Groves, 1985). This organization is noted for its easy formation because it does not require many capital or costly legal procedures to bring it into existence. It has continuity because the death of a member does not affect the continuity. A form of high standard of living is encouraged among members unlike some other known business organizations. For example, the societies provide essential commodities to members at appropriate prices thereby enabling them to consume goods they would ordinarily not have been able to consume or acquire. They also encourage members to save and give credit facilities to the needy members. All these help the standard of living of members to improve considerably. Cooperatives sell their goods at controlled and stabilized prices, and also regulate the quantity of goods needed. These activities help to fight inflation and deflation (CBN, 2005). There is good cordial inter personal relationship among members of the society and their employed staff (Kareem et al, 2012). Akinwunmi (2006) is of the view that the cooperative movement if properly organized can facilitate the distribution of goods to all parts of the country at affordable prices. In Nigeria, he argues that part of the goods imported by the Nigerian National Supply Company (NNSC) is distributed through consumer cooperatives. In addition, the cooperative provides avenue through which the masses may be involved in the production and distribution of goods and services. The modern cooperative movement in Nigeria started when C. F. Strickland was appointed in 1933 to look into the possibility of introducing cooperative societies into the country. Strickland's report came out in 1934, and reported that cooperatives be established in Nigeria for the following reasons: to eliminate exploitation by middle men; for producers to deal directly with the entrepreneurs, producers and buyers; for members to benefit from the extension of the Department of Agriculture; other requisite know-how to produce high quality cotton, cocoa, and palm produce to get higher prices; to provide production credit to members; and to do away with high interest loans. To promote cooperative spirit in a social system that already provides the fundamental rudiments of cooperatives (Alaba et al, 2007; Kareem et al, 2012). Sequel to Strickland's report, the first Cooperative Ordinance in Nigeria was passed in 1935. Later in 1936, Faulker was appointed the Registrar of Cooperatives and the control of cooperatives gradually shifted from the Agricultural Department, and it empowered the registrar of cooperatives to register, inspect, audit, hold inquiries and settle disputes and 

ISSN (online) - 2521-1242 ISSN (print) - 2521-1250

liquidate unsuccessfully registered cooperatives. The ordinance was in operation until the three regional governments of the east, north and the west) started adopting their own cooperative society laws. Before this time, there was a Cooperative Federation Limited, having its headquarters at Ibadan. However, as from 1952, onwards, each of the regions had her own cooperative department under different registrars; and Ibadan ceased to be the head-office of Nigerian cooperative societies.

Challenges of Cooperative Societies. Cooperatives all over the world are in a state of flux. Cooperatives face one or more of the following crises: crisis of ideology, crisis of capital, crisis of credibility and crisis of management (Chaddad, 1970; Ijere, 1986). Cheney (1995) identified five challenges facing cooperatives. These are cultural transformation, competition and expansion, wage solidarity, centralization and reorganization, programme to increase productivity and participation. Groves (1985) on the other hand, posits that one of the major problems of cooperatives is how to keep balance in the two parts of cooperative business, efficiency and democracy since those who are charged with the operation of a cooperative chiefly the board and manager must serve two masters: the imperatives of good business practice and the social purpose of a community of people. Hence, to maintain their special character, cooperatives must be two things in one: a business organization and a social movement (Emelianoff, 1942). This is what makes a cooperative a business enterprise with a human face and so, very difficult to manage. In striving for efficiency, cooperatives often tend to imitate other business, but in pursuing a social purpose they bring out the features, which make them different (Onaolapo and Oladejo, 2011).

\section{Cooperatives as Engines of Sustainable Economic Growth}

It could still be argued that the promotion of cooperatives can lead the renaissance for the revival of global economy (Akinwunmi, 2006). Aresvik (2006) posit that cooperatives are the ones that are more relevant than ever if the world looks ahead at the development challenges and opportunities the job faces over the coming decades. He further argues that cooperatives can offer the chances of making extreme poverty and deprivation history, to secure social inclusion and to reconcile economic and social objectives. Thus, these organizations are capable of creating wealth for the poor and creating jobs for the millions of the unemployed. Cooperatives and other social economic enterprises have shown that they have the capacity to reach many of the poor (Hammer, 2001). A recent study by the ILO and the International Cooperative Alliance (ICA) titled "Cooperatives and Sustainable Development Goals" highlights the contributions that cooperative enterprises are making to sustainable development and their potential to do much more from creating employment and enhancing gender equality, providing clean energy and financial inclusion to ensuring food security and extending social protection. Kareem et al, (2012) opines that, cooperatives have an outstanding track record of overcoming multiple forms of exclusion in rural areas and are present in all sectors of Nigeria and world economies. They thus respond to the triple bottom line of sustainable development, economic development, social justice and environmental protection. Cooperatives play an essential role in complementing conventional markets and government action.

\section{Theoretical Review}

\section{Economic Theory of Cooperatives}

Helmberger and Hoos (1962) can be regarded as having developed the first complete mathematical model of behaviour of an agricultural cooperative. Sexton (1995: 92), who provides a brief overview of developments in the economic theory of cooperatives in the US prior to Helmberger and Hoos' paper (see also LeVay, 1983; Sexton, 1984), considers their paper as "a landmark in the economic theory of cooperatives." Helmberger and Hoos (1962) use the neo-classical theory of the firm to develop short-run and long run models of a cooperative (including behavioral relations and positions of equilibrium for a cooperative and its members under different sets of assumptions) using traditional marginal analysis. In their model, the cooperative's optimization objective is to maximize benefits to members by maximizing "the per unit value or average price by distributing all earnings back to members in proportion to their patronage volume or use" (Torgerson et al., 1998: 5). Sexton (1995) regards this "landmark" paper so highly because (1) the (correct) analysis of cooperative and member behaviour is based on a clear set of assumptions; (2) the model clearly distinguishes between short and long-run behaviour in a cooperative; and (3) based on these characteristics, the model set the stage for further advances in cooperative theory in the 1970s and 1980s. Torgersonet al. (1998) contend that Philip (1986), Laidaw (1974) \& Kareem et al (2012) made a major contribution to understanding the internal economics of cooperatives with his conception of the cooperative as a form of vertical integration, and his focus 
on the structural and functional relationships of members (the principals) to their cooperative marketing organization (the agent). His model was later refined by Oja (1983), Phillips (1953) and Hart \& More (1990). They presents an overview of the debate on the Helmberger-Hoos and Phillips models, with the former initially having the greatest support among economists, although their contribution has also been criticized (e.g., LeVay, 1983; Lopez and Spreen, 1985; Sexton, 1986). Sexton (1995: 94) views this debate as "primarily one of semantics," and considers the issue not important to understanding cooperatives. He sees the development of alternative models as application of advances in economic theory of cooperatives reflecting "the richness of the environments in which cooperatives operate and the need to have alternative models that apply in different settings" Parfit (1984), Rainforest (2003) and Torgersonet al. (1998) also contribute to this debate. Over the past few decades, the rapidly changing economic environment, reflected in increasing globalization and agricultural industrialization, has led many agricultural cooperatives to undertake substantial structural changes in order to adapt to the new situation. Royer (1999), for example, mentions that in addition to mergers, consolidations and acquisitions (horizontal and vertical restructuring), cooperatives have become increasingly involved in fundamental institutional changes The criticisms of the neoclassical paradigm led to the development of alternative models of the firm based on other assumptions (e.g., maximizing rate of growth, sales, and firm size subject to a profit constraint), focusing on the process of decision-making within the firm (i.e., rejecting maximizing behaviour), and eliminating some of the unrealistic conditions of the model (e.g., by considering utility maximization, positive transaction and information costs, and alternative property rights structures). The role of positive transaction costs and variable property rights has given economists new insights into the existence of firms including cooperatives (MMunnad, 1993). The evolution of alternative forms of business organization and the choice of organizational form aimed at minimizing both production and exchange costs.

\section{Research method}

For the purpose of this study, the survey method was used. The ex-post facto method which involved the use of secondary data from the internet, journals, articles, and so on was also employed. The quantitative research design was adopted. Relevant data was collected at the same instance; a cross-sectional design was employed as well. The population was limited to all co-operators of the chosen cooperatives' societies in two (2) selected Paramilitary organizations in Ogun state. The two institutions chosen are Nigeria Security and Civil Defence Corps (NSCDC), and The Nigeria Immigration Service (NIS). The population of the study was not limited to people of different age group, gender, educational qualification, work experience, social status or hierarchy at work. After a proper survey, it was discovered that the total population of the selected cooperative society in NSCDC is 573 and the total population of the selected cooperative society in NIS is 697. For this study the sample size was determined using Yarmane formula. This formula is concerned with applying a normal approximation with a confidence level of $95 \%$ and a limit of tolerance level (error level) of 5\%. To this extent the sample size is determined by $\left[n=\frac{N}{1+N e^{2}}\right]$

Where: $\mathrm{n}=$ the sample size

$$
\begin{aligned}
& \mathrm{N}=\text { population } \\
& \mathrm{e}=\text { the limit of tolerance }
\end{aligned}
$$

Therefore, $n$

$$
\begin{aligned}
& =\frac{1270}{1+1270(0.05)^{2}} \\
& =\frac{1270}{1+4.619} \\
& =\frac{1270}{5.619} \\
& =226
\end{aligned}
$$

A sample size of two hundred and ninety-three (226) members out of the one thousand two hundred and seventy (1270) member population of the selected cooperatives in NSCDC and NIS. All member of the population had equal chances to be chosen as part of the sample because (226) questionnaires were administered randomly to the entire member population of the 2 selected cooperatives in NSCDC and NIS. The simple random sampling technique was adopted, whereby the researcher selected NSCDC and NIS as the sample 
ISSN (online) - 2521-1242 ISSN (print) - 2521-1250

frame to represent the entirety of the Paramilitary in Ogun State, Nigeria. Questionnaire was used as a research instrument. The questionnaire was divided in two broad categories. The first category was made up of personal data of respondents. Their; sex, age group, educational qualification, position occupied in firm and years of work experience. The second category comprised the body of the questionnaire that included all questions relevant to this research. It shall comprise of both negative and positive questions that will be structured on the basis of the six constructs of this research study. Likert-scale was used to measure opinions, where for positive questions (Strongly Agree $=5$, Agree $=4$, Undecided $=3$, Disagree $=2$, Strongly Disagree $=1$ ), and for negative questions (Strongly Agree $=1$, Agree $=2$, Undecided $=3$, Disagree $=4$, Strongly Disagree $=5$ ) . For the purpose of this research, the face validity approach was adopted where three professors of the faculty of Business Management Kwara State University checked through the questionnaire, made relevant corrections which was implemented and was subsequently approved on the basis that the instrument was appropriate. The data was analysed using manual and electronic based methods through the data preparation grid and statistical package for the social sciences, (SPSS). The utilization of structured grids allows specific responses to be located with relative ease and facilitate the identification of emerging patterns (Munn and Drever, 1990). Also, descriptive, statistical and content analyses techniques was used in the analysis of the data collected. This study made use of descriptive analysis to achieve the mean, frequency distribution and percentage results of the research work. It also made use of statistical tools which included: analysis of variance (ANOVA), correlation efficient and regression analysis in testing hypotheses if necessary. The study made use of Simple linear regression analysis and correlation analysis since they are measuring significance and effects and not relationship between variables. Towards this end, the test re-test reliability approach was adopted for the convenience of the researcher. Reliability was ensured by test re-test which yielded $r=0.69$ and internal consistency was measured by Cronbach Alpha of 0.885 .

Table: 1 . The detail of the reliability statistics

\begin{tabular}{|c|l|}
\hline Cronbach alpha & N of items \\
\hline .813 & 36 \\
\hline
\end{tabular}

Source: Field Survey (2015).

From Table Above, the Cronbach's Alpha coefficient is .813 for the 36 items that were analyzed together. It therefore indicates that the research instrument used for this study is highly reliable as it is more than the generally accepted reliability score of 0.7 . The data that was used for this study was obtained from both primary and secondary sources from the two (2) selected cooperatives from NSCDC and NIS.

Table 2. Distribution of respondents and response rate

\begin{tabular}{|l|c|c|}
\hline \multicolumn{1}{|c|}{ Respondents Occupation } & Questionnaire administered (sampled) & Percentage of total response (\%) \\
\hline Top Level & 19 & 9.0 \\
\hline Middle Level & 80 & 37.9 \\
\hline Lower Level & 112 & 53.1. \\
\hline Total & 211 & 100.0 \\
\hline Gender/Category & Questionnaire administered (sampled) & Percentage of total response (\%) \\
\hline Male & 119 & 56.4 \\
\hline Female & 92 & 43.6 \\
\hline No of Returned & 215 & 95.1 \\
\hline No of Not Returned & 11 & 4.9 \\
\hline Total no of Questionnaires & 226 & 100 \\
\hline Sourc Fid Surve 2018 & & \\
\hline
\end{tabular}

Source: Field Survey 2018.

\section{Data analysis and Hypothesis Testing}

Table 3. The Descriptive statistics of Cooperative Societies and Credit Delivery

\begin{tabular}{|c|c|c|}
\hline Responses & \multirow[t]{2}{*}{ Total $(\mathrm{N})$} & \multirow[t]{2}{*}{ Mean } \\
\hline Loan repayment \& savings plan of cooperative society & & \\
\hline The cooperative society gives financial aid to members & 215 & 4.66 \\
\hline The size of assistance given either financially or otherwise is unsatisfactory & 215 & 3.88 \\
\hline The repayment period of the loan given is very satisfactory & 215 & 3.89 \\
\hline Saving with the cooperative society has improved my standard of living & 215 & 3.69 \\
\hline The savings plan is rigid and unsatisfactory & 215 & 3.89 \\
\hline Modus operandi of the cooperative society \& membership of cooperative society & Total & Mean \\
\hline The mode of operation of this cooperative is complicated & 215 & 3.84 \\
\hline The leaders of the cooperative is free of corruption & 215 & 3.78 \\
\hline The structure of the cooperative society is good & 215 & 3.86 \\
\hline The electioneering process of choosing the leaders of the cooperative society is clean and just & 215 & 3.88 \\
\hline Membership in the cooperative society is always increasing & 215 & 3.79 \\
\hline
\end{tabular}




\section{Test of Hypotheses and Discussion of Results}

After a careful and systematic analysis of the respondent's responses to the research. questions formulated; hypothesis earlier submitted were tested using Statistical Packages for the Social Sciences (SPSS 20.0).

\section{Hypothesis 1:}

$\mathbf{H}_{\mathbf{0}}$ : Loan repayment and savings plan does not affect the satisfaction of members of cooperative societies in Paramilitary in Ogun state

\section{Non-parametric Correlations}

Table 4. Correlations

\begin{tabular}{|l|l|l|l|l|}
\hline & & & $\begin{array}{l}\text { My experience in the coopera- } \\
\text { tive society has been satisfac- } \\
\text { tory }\end{array}$ & $\begin{array}{l}\text { The repayment period of } \\
\text { the loan given is very sat- } \\
\text { isfactory }\end{array}$ \\
\hline Spearman's rho & $\begin{array}{l}\text { My experience in the cooperative } \\
\text { society has been satisfactory }\end{array}$ & Correlation Coefficient & 1.000 & $.746(* *)$ \\
\hline & & Sig. (2-tailed) &. & .000 \\
\hline & & $\mathrm{N}$ & 211 & 211 \\
\hline & $\begin{array}{l}\text { The repayment period of the loan } \\
\text { given is very satisfactory }\end{array}$ & Correlation Coefficient & $.746(* *)$ & 1.000 \\
\hline & & Sig. (2-tailed) & .000 &. \\
\hline & & $\mathrm{N}$ & 211 & 211 \\
\hline
\end{tabular}

** Correlation is significant at the 0.01 level (2-tailed).

Source: Authors Computation, 2018.

\section{Decision Rule}

If the $\mathrm{P}$-value is less than $5 \%(\mathrm{P}<0.05)$, then the null hypothesis is rejected, otherwise accepted.

\section{Interpretation of Result}

The result above shows a strong positive correlation existing between the dependent and independent variable with the $r$ value of 0.746 . Therefore, there is a significant relationship between loan repayment, savings plan and satisfaction of members of cooperative societies in Paramilitary in Ogun state.

\section{Hypothesis 2:}

$\mathbf{H}_{\mathbf{0}}$ : Modus operandi of cooperative societies in Paramilitary in Ogun state does not affect membership

\section{Nonparametric Correlations}

Table 5. Correlations

\begin{tabular}{|l|l|l|l|l|}
\hline & & & $\begin{array}{l}\text { The mode of operation of co- } \\
\text { operative is complicated }\end{array}$ & $\begin{array}{l}\text { Membership in the cooperative } \\
\text { society is always increasing }\end{array}$ \\
\hline $\begin{array}{l}\text { Spearman's } \\
\text { rho }\end{array}$ & $\begin{array}{l}\text { The mode of operation of co- } \\
\text { operative is complicated }\end{array}$ & Correlation Coefficient & 1.000 & .630 \\
\hline & & Sig. (2-tailed) &. & .000 \\
\hline & $\mathrm{N}$ & & 211 & 211 \\
\hline & $\begin{array}{l}\text { Membership in the coopera- } \\
\text { tive society is always increas- } \\
\text { ing }\end{array}$ & Correlation Coefficient & .630 & 1.000 \\
\hline & & Sig. (2-tailed) & .000 &. \\
\hline & $\mathrm{N}$ & 211 & 211 \\
\hline
\end{tabular}

Source: Authors Computation, 2018.

\section{Decision Rule}

If the $\mathrm{P}$-value is less than $5 \%(\mathrm{P}<0.05)$, then the null hypothesis is rejected, otherwise accepted. 
The result above shows a strong positive correlation existing between the dependent and independent variable with the $r$ value of 0.630 . Hence, we conclude that there is a significant relationship between modus operandi of cooperative societies and membership in Paramilitary in Ogun state.

\section{Discussion of findings}

From the findings, it is evident that interest rate of cooperative societies is a significant predictor of patronage of the cooperative, it also showed that there is a relationship between loan repayment periods, savings plan and the satisfaction of members of the cooperative society. The mode of operation of any cooperative society will have effect on sustaining existing member or getting new ones. The finding of this study is in direction with the finding of Sharma and Petterson (2000). This suggests the need for the improvement in the performance of the cooperative societies. The findings of the study revealed that challenges of the contributions of cooperative societies to economic development, such as inadequate utilization of training facilities, poor integrative cooperation, lack of decision making contributes to the challenges affecting cooperatives societies.

\section{Conclusion}

This paper concludes that Cooperative societies from their antecedents have contributed to the development of growth drivers in Nigeria. Cooperatives have always promoted welfare of members through provision of loans, funding, provision of entrepreneurship, promotion of establishment of small scale industries, promotion of small holder agriculture, etc. The findings revealed that in spite of these efforts, cooperatives are still faced with several challenges that include lack of adequate fund among its members, non-utilization of training educational opportunities, etc. Reform of the cooperative policy framework, including legal and regulatory procedures is desirable. Other areas needing attention are problems associated with management and leadership skills in the societies as well as the need to strengthen the cooperative governance system. Reports from respondents has shown that cooperative societies in this country have witnessed tremendous successes, they have some retrogressive issues that tend to often stall the good will, progress and prosperity of these societies. Some of the issues listed in this paper include poor management and lack of trained staffs, insufficient financial resources on the part of members, dishonesty, corruption and gang up by the capitalists to frustrate cooperative advancement and growth in order to protect their own business.

\section{Implications for Future}

The need for the improvement in the performance of the cooperative societies cannot be overemphasized. There is a significant relationship between loan repayment, savings plan and satisfaction of members of cooperative societies in Paramilitary in Ogun state. Based on the findings, the following implication are important to provide the solution to the problem associated to the cooperative society in order to increase their performance in loan repayment and savings plan in the future. The credit agencies should always endeavor to draw a more convenient disbursement and amortization schedule to conform to economic needs. That is, loan must be adapted to the peculiar needs of the cooperators and repayment condition should be flexible enough to allow for variation and uncertainties in cooperative income. Organizing workshop and seminar for cooperators on how to use the loan in other to yield returns in the investment at end of the business will leads to sustainable growth. Challenges of the contributions of cooperative societies to economic development, such as inadequate utilization of training facilities, poor integrative cooperation, and lack of decision making should be tackled to eradicate the challenges affecting cooperatives societies for future occurrences.

\section{Recommendations}

Base on the results of findings, the researchers hereby make the following recommendations:

i. The Federal Government of Nigeria should put in place the necessary infrastructure like regular power supply, good roads, water, and enhanced security across the states in order to encourage setting up of businesses from loans or other gains from cooperative societies.

ii.Cooperative society should dialogue with the Central Bank of Nigeria (CBN) and the Bankers Committee on how to make the Equity Investment Scheme work. A Credit Guarantee Scheme will be a risk-mitigating mechanism for Public and Civil Servants.

iii.Active collaboration of cooperative society with the Organized Private Sector, Bank of Industry as well as the Federal Ministry of Trade and Investment could go a long way in ensuring that the objectives of this Agency are realized for the benefit of the average Nigerian. 


\section{Limitations of the study}

It is important to note that this research engaged a very small sample population thus foreclosing the possibility of generalization. Furthermore, this study relied on self-report measures which can potentially lead to subjective bias among the respondents.

\section{Suggestions for Further Studies}

A research of this magnitude cannot be said to cover every aspect. Therefore, further research should be conducted in the following possible areas of study, such as: to investigate the effect of cooperative society on the in standard of living of members.

\section{References}

1. Adekunle, J \& Henson, S. (2007). Cooperative organizational strategies: A neo-institutional digest. Journal of Cooperatives 14, 44-67

2. Akinwumi, J. (2006). Road Map to re-engineering Cooperatives in Nigeria; A paper presented at the south west cooperative leaders conference, organized by cooperative federation of Nigeria South west zone at Obisesan Hall, Ibadan, September 7th, 2006.

3. Alaba, T.J, Alaba, K.K. \& Ahiowa, A. (2007). Principal-agent relationships in agricultural cooperatives: An empirical analysis from rural. Journal of Cooperatives, 13, 21-33

4. Anderson, J.S. \& Sullivan, P. (1993). Economic nature of the cooperative association: A retrospective appraisal. Journal of Agricultural Cooperation, 9, 86-94.

5. Aresvik, M. (2008). Grameen Bank, Microcredit and Millennium Development Goals; www.grameen.comwww.grameen-info.org(Accessed 05 March 2015).

6. Aryeetey, N. (1997). Social Capital, Microfinance and the Politics of Development. Feminist Economics, $8(1), 1-24$.

7. Asaolu, T. O. (2004). Evaluation of the performance of the Cooperative Investment and Credit Societies (CICS) in financing Small-Scale Enterprises (SSEs) in Osun State, Nigeria.

8. Central Bank of Nigeria (2005). Microfinance Policy, Regulatory and Supervisory Framework.

9. Chaddad, J. M. (1970). AO and principles of cooperatives and Applications in different Asian countries (in Ilo Reports, Genva).

10. Cheney. (1995). Cooperatives: Pathways to Economic, Democratic and Social Development in the Global Economy.

11. Emelianoff, P. L. (1942). An Evaluation of Funding Arrangements for Small and Medium Scale Enterprises (SMEs) in Nigeria. PhD Dissertation, British West Indies: Project Department of Business and Management Studies, St Clements University.

12. Fornell, M.E. (1992). Putting theories of the firm in their place: A supplemental digest of the new institutional economics. Journal of Cooperatives 14, 68-76.

13. Garnett, H.T. (2012), the Evolution of financial Cooperatives in Nigeria: Do they have a place in financial intermediation? International Year of Cooperatives (ED Oluombo 2012).

14. Gounans, L. M. (2003); Attitudes Toward Cooperative Strategies: A Cross-Cultural Analysis of Entrepreneurs. Journal of International Business Studies.2(3). 56-71

15. Groves, H (1985). Making Cooperative societies work for you. Sunday business in Sunday Punch Newspa18th, February, 7.

16. Hammer, M. (2001). The Superefficient Company" Harvard Business Review, 79, 82-91.

17. Helmberger, P. \& S. Hoos. (1962). Cooperative Enterprise and Organization Theory. Journal of Farm Economics, 44, 275-90.

18. Igwe, C. E. (1991). Relative Efficiency of Cooperative and Non-Cooperative Farmers in Food Production in Imo State. Press in AMSE Transactions, France 8, (4).72-75.

19. Ijere, M.O. (1986) Nigeria Agricultural Outlook, Nigeria Association of Agricultural Economists, Nsukka: University of Nigeria.

20. Kareem, R.O, Arigbabu, Y.D, Akintaro, J.A and Badmus, M.A (2012). The Impact of Co-Operative Society on Capital Formation (A Case Study of Temidere Co - Operative and Thrift- Society, Ijebu- Ode, 
Financial Markets, Institutions and Risks, Volume 3, Issue 2, 2019

ISSN (online) - 2521-1242 ISSN (print) - 2521-1250

Ogun State, Nigeria) Global Journal of Science Frontier Research Agriculture and Veterinary Sciences, (12) $11.17-29$

21. Laidlaw, J. (1974). Self-Interest and the Concept of Self-Sacrifice, Canadian Journal of Philosophy 10 (1980): 105-118.

22. LeVay, C. (1983). Some Problems of Agricultural Marketing Co-operatives' Price/Output Determination in Imperfect Competition. Canadian Journal of Agricultural Economics 31, 105-10.

23. Lopez, D. \& Spreen G. (1985). Private Sector Development and Poverty Reduction in Nigeria: Mainstreaming the Small Medium Enterprises Sector ', The Nigeria Economic Submit Group (NESG) Economic Indicators, 11(1), $18-23$

24. Micheal, M. (2009). Principles of Research Methodology. New York Press.

25. Munnad, D. (1993). Cooperative policy and village development in Northern Nigeria. J. Heyeretal(eds). $259-8$

26. Hart O \& Moore J (1990). Property rights and the nature of the firm. Journal of Political Economy 98(6), 1119-1158

27. Oja, I. (1993). Cooperatives Today and Tomorrow, Genera.

28. Olumidu, H. (2001). Poverty Reduction Through the Use of Cooperative Societies. Kaduna.

29. Onaolapo and Oladejo (2011). Impact of cooperative financing on MDGS of poverty eradication; lesson from nigeria research. Journal of finance and accounting, (2)11.

30. Osuala E.C. (1982). Introduction to Research Methodology. New York: Exposition Press.

31. Parfit, Derek. (1984). Reasons and Persons, Oxford: Clarendon Press.

32. Patterson C, Johnson, J\&Spreng ML (1999). The internal organization of the cooperative firm: An extension of a new institutional digest. Journal of Cooperatives 14, 77-85.

33. Philips, SJ (1986). The costs and benefits of ownership: A theory of vertical and lateral integration. Journal of Political Economy, 94(4), 691- 719.

34. Royer, T. (1994). Imperfect Information, Social Capital and the Poor's Access to Credit. IRIS Centre Working Paper, 234, 1-25.

35. Sexton, P. (1995). Measuring Effectiveness of Social Capital in Microfinance: A Case Study of Urban Microfinance Programme in India. International Journal of Social Inquiry, (3)2, 25-43.

36. Sexton, R.J. Wilson, B.M. \& J.J. Wann. (1989). Some Tests of the Economic Theory of Cooperatives: Methodology and Application to Cotton Ginning. Western Journal of Agricultural Economics, 14,56-66.

37. Sharma, N. \& Patterson, P.G. (1999). A model of relationship, commitment among professional services. Journal of service marketing, 13(2), 151-170.

38. Sharma, N. \& Patterson, P.G. (2000). Switching costs, alternatives attractiveness and experience as moderators of relationship commitment in professional, consumer services. International journal of services industry management, 11(5), 470-490.

39. Torgerson, J.K. (1998). Marketing Cooperatives in Mixed Duopolies. Journal of Agricultural Economics $46,33-45$. 